\title{
Antagonistic analogs of growth hormone-releasing hormone increase the efficacy of treatment of triple negative breast cancer in nude mice with doxorubicin; A preclinical study
}

\author{
Roberto Perez ${ }^{1,2}$, Andrew V. Schally ${ }^{1,2,3,4,5,6}$, Petra Popovics ${ }^{1,2,7,8}$, Renzhi Cai ${ }^{1,2,3}$, Wei \\ Sha ${ }^{1,2,4}$, Ricardo Rincon ${ }^{1,2}$ and Ferenc G. Rick ${ }^{1,2,9}$ \\ ${ }^{1}$ Veterans Affairs Medical Center, Miami, FL \\ 2 South Florida VA Foundation for Research and Education, Miami, FL \\ ${ }^{3}$ Department of Pathology, University of Miami, Miller School of Medicine, Miami, FL \\ ${ }^{4}$ Division of Hematology/Oncology, University of Miami, Miller School of Medicine, Miami, FL \\ ${ }^{5}$ Division of Endocrinology, Department of Medicine, University of Miami, Miller School of Medicine, Miami, FL \\ ${ }^{6}$ Sylvester Comprehensive Cancer Center, Miller School of Medicine, University of Miami, Miami, FL \\ 7 Division of Cardiology, Department of Medicine, Miller School of Medicine, University of Miami, Miami, FL \\ ${ }^{8}$ Department of Medicine III, Technical University Dresden, Dresden, Germany \\ ${ }^{9}$ Department of Urology, Herbert Wertheim College of Medicine, Florida International University, Miami, FL \\ Correspondence to: Roberto Perez, email: Robert.perez.phd@gmail.com
}

Andrew V. Schally, email: andrew.schally@va.gov

Keywords: triple negative breast cancer, drug resistance, combination therapy, growth-hormone-releasing hormone, antagonist, GHRH analogs

Received: October 12, 2014

Accepted: October 23, 2014

Published: October 24, 2014

This is an open-access article distributed under the terms of the Creative Commons Attribution License, which permits unrestricted use, distribution, and reproduction in any medium, provided the original author and source are credited.

\section{ABSTRACT}

Introduction: This study evaluated the effects of an antagonistic analog of growth hormone-releasing hormone, MIA-602, on tumor growth, response to doxorubicin, expression of drug resistance genes, and efflux pump function in human triple negative breast cancers.

Methods: HCC1806 (doxorubicin-sensitive) and MX-1 (doxorubicin-resistant), cell lines were xenografted into nude mice and treated with MIA-602, doxorubicin, or their combination. Tumors were evaluated for changes in volume and the expression of the drug resistance genes MDR1 and NANOG. In-vitro cell culture assays were used to analyze the effect of MIA-602 on efflux pump function.

Results: Therapy with MIA-602 significantly reduced tumor growth and enhanced the efficacy of doxorubicin in both cell lines. Control HCC1806 tumors grew by $435 \%$, while the volume of tumors treated with MIA-602 enlarged by $172.2 \%$ and with doxorubicin by $201.6 \%$. Treatment with the combination of MIA-602 and doxorubicin resulted in an increase in volume of only $76.2 \%$. Control MX-1 tumors grew by $907 \%$, while tumors treated with MIA-602 enlarged by $434.8 \%$ and with doxorubicin by $815 \%$. The combination of MIA-602 and doxorubicin reduced the increase in tumor volume to $256 \%$. Treatment with MIA-602 lowered the level of growth hormonereleasing hormone and growth hormone-releasing hormone receptors and significantly reduced the expression of multidrug resistance (MDR1) gene and the drug resistance regulator NANOG. MIA-602 also suppressed efflux pump function in both cell lines.

Conclusions: We conclude that treatment of triple negative breast cancers with growth hormone-releasing hormone antagonists reduces tumor growth and potentiates the effects of cytotoxic therapy by nullifying drug resistance. 


\section{INTRODUCTION}

In the United States alone, nearly 200,000 women are afflicted with breast cancer each year and 41,000 die as a result of their malignancy.[1] Breast cancer is the leading cause of mortality in Hispanic and AfricanAmerican women and the second most common cause of cancer-related death of women. The US figures can be extrapolated to approximately 4 million new cases and 820,000 deaths per year, worldwide.

Breast cancer is a very heterogeneous disease. The subtype defined as triple negative breast cancer (TNBC) is negative for estrogen receptor, progesterone receptor, and the human epidermal growth factor receptor 2 (Her2).[2] TNBC accounts for $10-15 \%$ of all breast cancer cases and has a higher rate of mortality than other malignancies. The TNBC phenotype is hereditary, affects younger women, is more invasive, and has a much poorer prognosis.[3] These cancers are extremely resistant to the treatment options available for other breast cancers, with drug efflux being the primary mechanism of resistance.[4] This accounts for the low survival rate of women with TNBC.[5] Alternate treatment strategies must therefore be devised to address this clinical deficiency.

Growth hormone releasing hormone (GHRH) is a neuropeptide hormone, secreted by the hypothalamus, which regulates the synthesis and release of growth hormone by the pituitary.[6] Growth hormone subsequently stimulates the release of hepatic insulinlike growth factor, which is a major anabolic growth factor and a potent mitogen for many neoplasms.[7-9] Additionally, GHRH and GHRH receptors (GHRH-R) are not confined to the hypothalamic-pituitary axis, but are also produced by various extra-hypothalamic sites.[10-16] Biologically active GHRH, mRNA for GHRH, GHRH-R, and splice variants of GHRH-R have been identified in surgical specimens and tumor cell lines of a multitude of human cancers, including various types of breast cancer. [17-28] Much evidence indicates that GHRH acts as an autocrine/paracrine growth factor in many human cancers $[6,23,29-31]$ including that of the breast.[32] Pituitarytype GHRH-R and splice variant 1 of GHRH-R appear to mediate the direct effects of GHRH and its analogs on tumors.[33] In vitro and in vivo proliferation of various human cancers is suppressed by antagonistic analogs of GHRH (referred to as "GHRH antagonists").[8, 34, 35] These findings support the concept of GHRH as a growth factor for tumors and suggest that GHRH-R could be used as a suitable therapeutic target.

We have recently reported that the GHRH antagonist, MIA-602, suppresses the expression of inflammatory cytokines in human TNBC tumors xenografted into nude mice.[36] Cytokines have been shown to play a major role in the cellular signaling involved in the pathogenesis of breast cancer.[37-39] In this study, we used HCC1806 and doxorubicin-resistant
MX-1 human TNBC cell lines xenografted into nude mice to evaluate the effects of a GHRH antagonist (MIA-602) alone and in combination with doxorubicin. We examined the effects of treatment on tumor growth, drug resistance, GHRH-R levels, expression of MDR1 and Nanog, and efflux pump activity.

\section{RESULTS}

\section{Effect of treatment with MIA-602, doxorubicin, or their combination on the growth of xenografts of HCC1806 and MX-1 human TNBC}

Treatment of nude mice bearing human TNBC tumors was initiated after the tumors had reached a volume of $\sim 100 \mathrm{~mm}^{3}$ and lasted for five weeks. Control HCC1806 tumors grew by $435.3 \%( \pm 41.6 \%)$ of the initial tumor volume by week five, while tumors treated with MIA-602 augmented by only $172.2 \%( \pm 15.1 \%)$, significantly $(\mathrm{P}<0.001)$ less than controls. Tumor volume of mice given doxorubicin increased by $201.6 \%$ ( $\pm 7.1 \%)$ and was also significantly $(\mathrm{P}<0.001)$ reduced compared to controls. Thus, treatment with MIA-602 reduced the growth of $\mathrm{HCC} 1806$ tumors by $60 \%$ and doxorubicin by $54 \%$ compared to controls. The combination of MIA-602 and doxorubicin had the greatest inhibitory effect and diminished the growth of HCC1806 tumors by $83 \%$ versus controls. The treatment with the combination of MIA-602 and doxorubicin resulted in the smallest increase in tumor

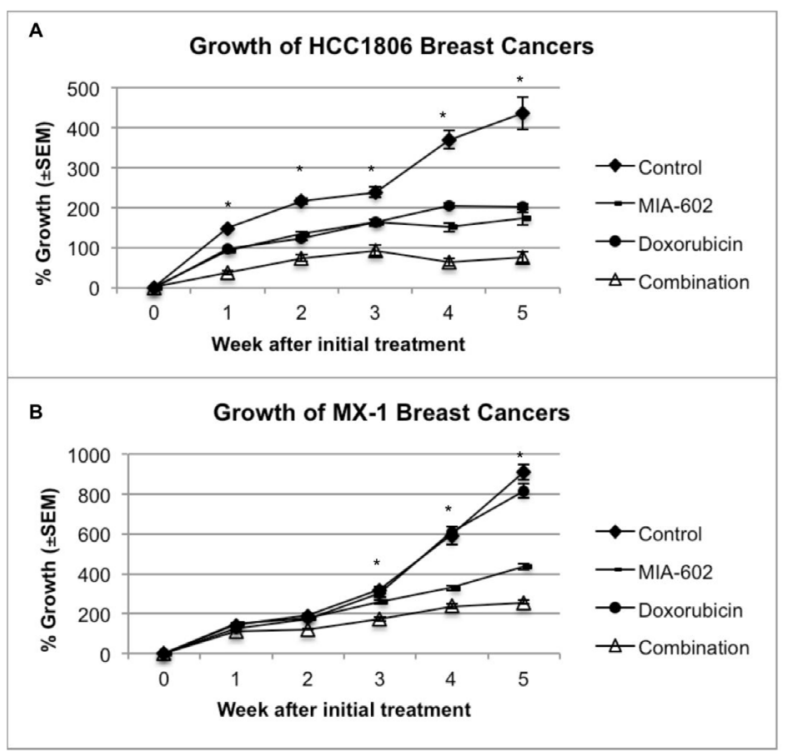

Figure 1: A. HCC1806 tumors responded significantly better to combination treatment than to either MIA-602 or doxorubicin alone. B. Treatment of MX-1 tumors (doxorubicin resistant) with doxorubicin/MIA-602 combination resulted in elimination of resistance to doxorubicin. Vertical bars indicate \pm SEM. * Combination vs. control ( $\mathrm{P}<0.001)$, MIA-602 $(\mathrm{P}<0.05)$, and doxorubicin $(\mathrm{P}<0.001)$. $\mathrm{N}=16$ tumors. 
volume of $76.2 \%( \pm 13.6 \%)$. The growth of tumors treated with the combination was significantly smaller than that of controls $(\mathrm{P}<0.001)$ and tumors treated with either MIA$602(\mathrm{P}<0.05)$ or doxorubicin $(\mathrm{P}<0.001)$ (figure $1 \mathrm{a})$.

Control MX-1 tumors grew by $907.4 \%$ $( \pm 37.4 \%)$ of the initial tumor volume by week five, but those treated with MIA-602 increased by $434.8 \%$ $( \pm 12.9 \%)$; significantly ( $\mathrm{P}<0.001)$ less than controls. Not surprisingly, the growth of tumors treated with doxorubicin, which attained a volume $814.9 \%( \pm 34.7 \%)$ of the initial size, was not significantly different than controls. Treatment with the combination of MIA-602 and doxorubicin led to an increase in final tumor volume of only $256.0 \%$ ( $\pm 10.3 \%)$. Treatment with MIA-602 reduced the growth of MX-1 tumors by $52 \%$ and doxorubicin by only $10 \%$ compared to controls. The combination of MIA602 and doxorubicin decreased growth of MX-1 tumors by $72 \%$. Combination therapy resulted in significantly reduced growth compared to controls $(\mathrm{P}<0.001)$, and tumors treated with MIA-602 $(\mathrm{P}<0.05)$ or doxorubicin $(\mathrm{P}$ $<0.001$ ) (figure 1b).

\section{Expression of GHRH and GHRH-R genes by xenografts of HCC1806 and MX-1 human TNBC}

Protein and mRNA for GHRH and GHRH-R were expressed in both HCC1806 and MX-1 human TNBC cell lines as determined after five weeks of treatment using qRT-PCR. The expression of GHRH and GHRH-R genes by HCC1806 tumors was significantly $(P<$ 0.05 ) suppressed by treatment, in-vivo, with MIA-602. HCC1806 tumors treated with the GHRH antagonist for five weeks expressed 91.8\% $( \pm 3.8 \%)$ less GHRH and the levels of GHRH-R were $59.4 \%( \pm 5.7 \%)$ lower than in controls. Expression of GHRH and GHRH-R genes by MX-1 tumors was also significantly $(P<0.05)$ reduced by therapy with MIA-602. MX-1 tumors treated with

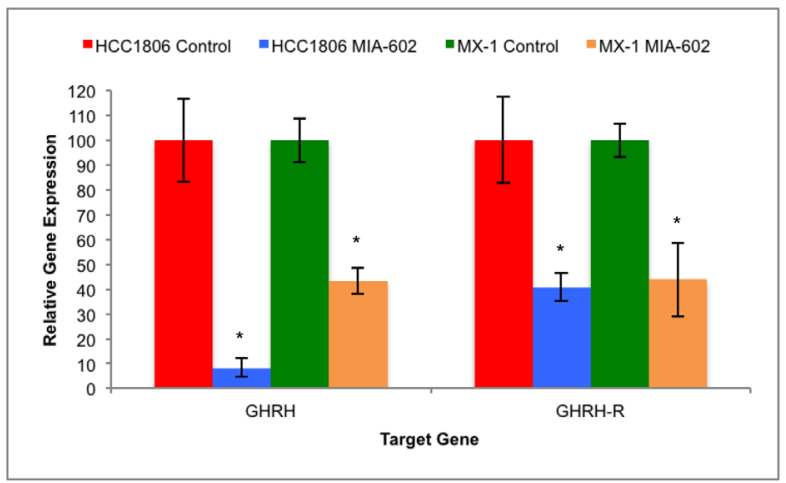

Figure 2: Treatment of HCC1806 and MX-1 human TNBC tumors with the GHRH antagonist MIA-602 significantly suppressed the expression of GHRH and GHRH-R genes. Vertical bars indicate \pm SEM, $\mathrm{n}=12$ tumors, $* P<0.01$ vs. control. the GHRH antagonist for five weeks expressed 56.2\% $( \pm 5.2 \%)$ less GHRH and $56.1 \%( \pm 14.9 \%)$ less GHRH-R than controls (figure 2).

\section{Expression of regulatory genes of drug resistance by xenografts of HCC1806 and MX-1 human TNBC}

The expression of the tumoral multidrug resistance gene (MDR1), which encodes P-glycoprotein, and NANOG, a stem-cell marker and a regulator of the expression of drug resistance genes, was determined using qRT-PCR.

In-vivo treatment of HCC1806 tumors with MIA602 , doxorubicin, or combination resulted in significant $(\mathrm{P}<0.01)$ suppression of MDR1 and NANOG gene expression relative to controls. The expression of MDR1 in tumors treated with combination was more powerfully suppressed than with either compound alone $(\mathrm{P}<0.001)$. Analysis of NANOG indicates that the combination treatment suppresses expression significantly $(\mathrm{P}<0.001)$ more than either compound alone (figure 3a). Therapy of doxorubicin resistant MX-1 tumors with MIA-602 or combination led to significant $(\mathrm{P}<0.05)$ reduction in MDR1 and NANOG gene expression relative to controls. The combination also significantly $(\mathrm{P}<0.05)$ suppressed the expression of MDR1 and NANOG genes compared to doxorubicin alone, which did not have a significant effect (figure 3b).

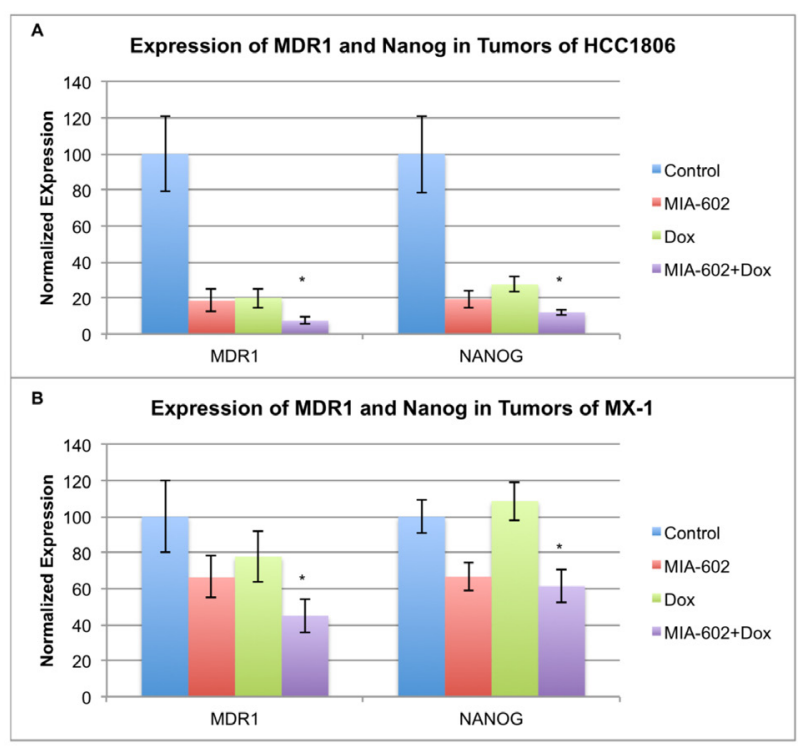

Figure 3: Expression of both NANOG and MDR1 was significantly suppressed by treatment with the MIA602/doxorubicin combination compared to MIA-602 or doxorubicin alone in A. $\mathrm{HCC} 1806$ and doxorubicin alone in B. doxorubicin resistant MX-1. Vertical bars indicate \pm SEM, $\mathrm{n}=12$ tumors, $* P<0.01$ vs. control. 


\section{Lowering of efflux pump activity in $\mathrm{HCC} 1806$ and MX-1 human TNBC cells}

Efflux pump function was determined using a fluorescent dye (Calcein AM) retention assay. [40] The cells were treated with $5 \mu \mathrm{M}$ GHRH antagonist, MIA602 , for 4 hours and retention of Calcein was determined. HCC1086 cells and MX-1 cells, treated with $5 \mu \mathrm{M}$ MIA- 602 , retained $7 \%$ and $40 \%$ more dye than controls, respectively. Both reductions in efflux pump function were significant compared to the respective controls $(\mathrm{P}<0.01)$ (figure 4).

\section{DISCUSSION}

Much information has now been accumulated concerning the role of GHRH, GHRH receptors, and receptor splice variants (SV) in carcinogenesis. The proliferation of various human cancers in vitro is suppressed by GHRH antagonists.[41] A report suggests that the dysregulation of GHRH expression or autocrine/ paracrine secretion contributes to the pathogenesis of breast and other cancers.[42] In vivo investiagtions have demonstrated the anti-tumor activity of GHRH antagonists against multiple cancer types. Studies on the effects of GHRH antagonists on prostate and lung cancers demonstrated their ability to modulate signaling pathways involved in cellular proliferation, survival, metastasis, and apoptosis.[43-45]

Increased expression of inflammatory cytokines correlates with higher tumor grade, greater metastatic potential, and higher incidence of resistance to treatment, all of which predict a poorer survival.[46] Among the roles of cytokines in breast cancer is their ability to regulate epithelial-mesenchymal transitions (EMT) and drug resistance.[38, 47, 48] In the course of EMT, expression of intercellular adhesion molecules, among other characteristics of an epithelial phenotype, is lost and cells acquire a stem-cell-like or "mesenchymal" phenotype. The resulting phenotype is highly motile and possesses stem-cell-like properties, a high degree of resistance to treatments, and an increased rate of drug efflux.[49-51]

Numerous studies have firmly established the regulatory role of inflammatory cytokines in cancer.[3, $37-39,46,47,50,52]$ Our group has recently reported the reduction in prostate size and suppression of inflammatory cytokines by GHRH antagonists in a rodent model of experimental benign prostatic hyperplasia (BPH).[53] We have also demonstrated similar effects of GHRH antagonists on in vivo cytokine gene expression by HCC1806 and MX-1 triple negative human breast cancer. Analysis of the genes expressed by tumors treated with MIA-602 indicates that it suppresses the expression of tumoral inflammatory cytokines.[36]

Studies on human cancer lines xenografted into nude mice have demonstrated anti-tumor activity of GHRH antagonists against multiple human cancer types. $[6,30,54]$ Evaluations of GHRH antagonists in prostate and lung cancers demonstrated their ability to modulate signaling pathways involved in cellular proliferation, survival, metastasis, and apoptosis.[23, 43, 44, 55] Among the affected pathways is the PI3K-AKT, which regulates inflammatory cytokines through NF- $\kappa \beta .[43,44$, 56] Activation of the NF- $\kappa \beta$ pathway by inflammatory cytokines has also been shown to enhance drug resistance in breast cancer. Analyses indicate that treatment with GHRH antagonists suppresses the expression of proinflammatory cytokines in BPH.[13, 53]

Cell lines used in this study (HCC1806 and MX1) were both susceptible to treatment with the GHRH antagonist, MIA-602. Tumors treated with MIA-602 showed a significant reduction in growth compared to controls. Combination of the GHRH antagonist with doxorubicin increased this inhibition of growth. Most importantly, MX-1 tumors, which are completely resistant to doxorubicin, were very responsive to the cytotoxic drug (doxorubicin) when it was administered in combination

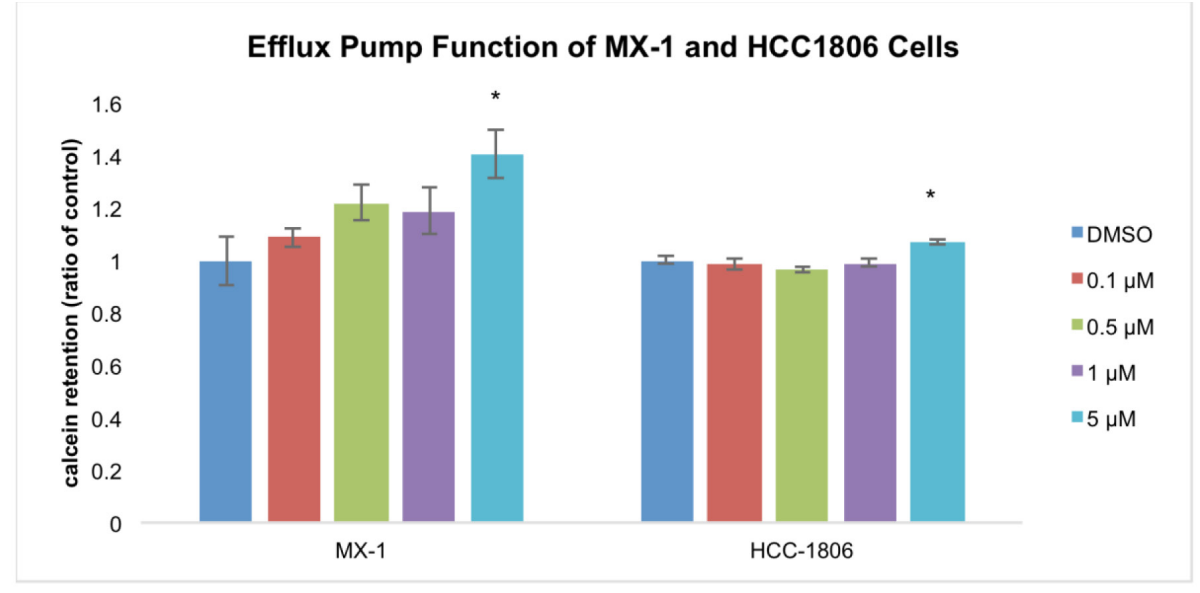

Figure 4: Efflux pump function assay. TNBC cells treated with MIA-602 have significantly reduced efflux pump function compared to controls as evidenced by the retention of fluorescent dye. Vertical bars indicate \pm SEM, $\mathrm{n}=9$ samples, ${ }^{*} P<0.01$ vs. control. 
with MIA-602. Real-time RT-PCR analysis of the MX-1 tumors indicates that the expression of genes involved in drug resistance was reduced by treatment with MIA602. The genes MDR1 and NANOG, both involved in the regulation and expression of efflux pump mechanisms, were significantly suppressed. Additionally, cells treated with MIA-602 showed a significant increases in Calcein dye retention, indicating that efflux pump function was reduced. These results illustrate the ability of GHRH antagonists to not only inhibit the growth of tumors, but also to enhance the effectiveness of other drugs by reducing resistance.

Several reports have detailed the effects of treatment with GHRH antagonists on the growth of breast cancers. $[6,20,57,58]$ The study presented herein illustrates the role of GHRH signaling in the regulation of drug resistance in TNBC. Our results also demonstrate the ability of a GHRH antagonist, MIA-602, to be a potential new treatment for drug resistant cancers. Our data suggest that changes in the expression of genes associated with drug resistance and cancer cell "stemness", induced by treatment with MIA-602, lead to a significant reduction in the efflux capacity of drug resistant cells. This results in the accumulation of the cytotoxic drug in cells with disabled efflux mechanisms and reduces resistance. This study illustrates the potential benefits of using GHRH antagonists for the treatment of cancers that are highly resistant to cytotoxic agents such as doxorubicin.

\section{METHODS}

\section{Drugs and Chemicals}

The GHRH antagonistic analog, MIA-602, was synthesized in our laboratory as previously described. $[7,59]$ For daily subcutaneous injection, MIA-602 was dissolved in a $0.1 \% / 10 \%$ DMSO/propylene glycol solution. Doxorubicin was dissolved in a sterile solution of $5 \%$ mannitol for weekly intravenous injection. For in-vitro studies, both MIA-602 and doxorubicin were dissolved in DMSO to a concentration of $10 \mathrm{mM}$ and $2.5 \mathrm{mM}$, respectively. The DMSO stock solutions were diluted with culture media keeping the final concentration of DMSO to less than $0.01 \%$.

\section{Animals}

Female nude mice (Harlan Laboratories) between 10 and 11 weeks of age ( $20 \mathrm{~g}$ body weight) were housed in a climate-controlled environment with a 12-h light/ dark cycle and were fed standard laboratory diet with water ad libitum. Body weights were determined weekly. All animals remained healthy throughout the experiment. Animal care was in accordance with institutional guidelines and complied with National Institutes of Health policy.

\section{Cell Culture}

Cultures of the human triple negative breast cancer cell line, HCC1806, were maintained in RPMI 1640 medium supplemented with $10 \%$ FBS. Flask cultures were kept in a humidified incubator in a $5 \% \mathrm{CO}_{2}$ atmosphere at $37^{\circ} \mathrm{C}$. Growth medium was replaced every 72 hours for two weeks. Cells were collected using $0.05 \%$ trypsin and incubating at $37^{\circ} \mathrm{C}$ for 3 minutes. Trypsin was inactivated with an equal volume of FBS containing medium and the cells were collected by centrifugation at $1000 \mathrm{x} g$ for 10 minutes.

\section{Study Design}

Donor animals were xenografted with $10^{5}$ cells and tumors were allowed to grow for 4 weeks. The tumors were collected from euthanized animals and cut into approximately $5 \mathrm{mg}$ fragments. Fragments were rinsed with sterile PBS and xenografted subcutaneously into both flanks of each animal. Tumors were allowed to grow to a mean volume of $75-100 \mathrm{~mm}^{3}$ prior to administration of the initial treatment. Animals were randomly assigned to one of four experimental groups. The control group remained untreated and the treated groups received daily

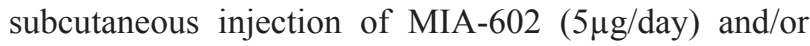
weekly intravenous (jugular) injections of doxorubicin $(2.5 \mathrm{nmol} / \mathrm{kg} / \mathrm{wk})$. Animals were treated for up to 5 weeks and tumor volume $(\mathrm{mm} 3)=($ length $\mathrm{x}$ width $\mathrm{x}$ height $\mathrm{x}$ 0.5236 ) and body weight were assessed weekly. Tumor inhibition (\%) was calculated according to the following formula: [(final volume control - initial volume control) - (final volume treated - initial volume treated)]/(final volume control-initial volume control) x 100 [60]. All animals were euthanized by cervical dislocation upon study completion and tumors collected postmortem.

\section{RNA Isolation}

Excised tumors were immediately cut into approximately $25 \mathrm{mg}$ pieces and submerged in RNAlater (Ambion) stabilization solution. After an overnight incubation at $4^{\circ} \mathrm{C}$, for thorough stabilization, samples were homogenized in lysis buffer and total RNA was isolated using the GE Illustra RNAspin Isolation Kit (GE Healthcare) according to the manufacturer's protocol. Contaminating DNA was eliminated with an on-column DNase treatment as part of the isolation procedure. Total RNA was quantified and assessed for purity using a Nanodrop spectrophotometer (Thermo Scientific). 


\section{SYBR Green-based RT-PCR Primer Design}

Gene expression was determined using qRT-PCR. All RNA targets were analyzed using custom designed oligonucleotide primers designed for use in SYBR green based qRT-PCR. The assays were painstakingly designed using extremely strict parameters in order to exclude non-human (mouse) templates and target regions of low energy secondary structures, maximizing both specificity and sensitivity. All assays were determined to produce a single product which was verified as the human target of interest by DNA sequencing.

Transcript specific primers were designed using the Beacon Designer software suite (Premiere Biosoft) with modified parameters. Primer searches were conducted to regions on mRNA sequences, obtained from the NCBI database, which were not homologous to the equivalent mRNA from mice (Mus musculus). The resulting humanspecific sequences were screened for regions of stable secondary structures $(\Delta \mathrm{G}<-3.0 \mathrm{Kcal} / \mathrm{mol})$, which were excluded from our primer search. Primer searches were optimized for reverse transcription at $52^{\circ} \mathrm{C}$ and fast cycling polymerase chain reaction at $57^{\circ} \mathrm{C}$. Primer hairpin energy was limited to $\Delta \mathrm{G}=-3.0 \mathrm{Kcal} / \mathrm{mol}$ and dimer energies were limited to $\Delta \mathrm{G}=-4.0 \mathrm{Kcal} / \mathrm{mol}$. Dimers including the last 3 bases of the 3' end of the primer were limited to $\Delta \mathrm{G}=-2.0 \mathrm{Kcal} / \mathrm{mol}$. Primers were designed to result in amplicons of 75-200 bp in length. Primer pairs that were less than $98 \%$ efficient were excluded. All primers used produce a single product of predictable and reproducible melting temperature ( $\mathrm{Tm})$. All primers were optimized and verified by sequencing the corresponding amplicons.

\section{Real-time Quantitative Reverse-Transcription Polymerase Chain Reaction (qRT-PCR)}

Gene expression analysis was conducted using onestep qRT-PCR with SYBR green chemistry. This method conducts the reverse transcription reaction and PCR in a single tube format from $20 \mathrm{ng}$ total RNA template. The production of the PCR amplified gene product is monitored using the fluorescence resulting from the binding of SYBR green to the double stranded DNA amplicons. Reactions were conducted in a CFX96 Real-Time System using the One-Step SYBR Green qRT-PCR reaction kit (Bio-Rad). Reactions were conducted in triplicate and normalized to three internal standard genes using the $\delta \delta \mathrm{Ct}$ method.[61]

\section{Efflux Pump Function Assay}

Multidrug resistance of MX-1 and HCC-1806 cells was measured by calcein retention assay according to the manufacturer's instructions (Cayman Chemical) [62]. Briefly, cells were seeded onto 96-well plates to 20,000 cells/well density. Two days later, culture medium was replaced with Optimem (Life Technologies) containing $0.1 \mu \mathrm{M}-5 \mu \mathrm{M}$ MIA-602 for 4 hours. Calcein-AM and Hoechst were added at the end of the treatment for 10 minutes and the developed fluorescence was measured in assay buffer in a Victor3 plate reader (Hoechst at excitation and emission wavelengths of $355 \mathrm{~nm}$ and 465 $\mathrm{nm}$, respectively and calcein at excitation and emission wavelengths of $485 \mathrm{~nm}$ and $535 \mathrm{~nm}$, respectively). Values of calcein retention (efflux function) were normalized to Hoechst nuclear staining (viable cell density).

\section{Statistical Analysis}

Prism 5 software (Graphpad Software, Inc.) was used for statistical evaluation of the data. Results are expressed as means \pm SEM. One-way ANOVA followed by Bonferroni $t$ test or a two-tailed Student's $t$ test was used where appropriate, and significance was accepted at $P<0.05$.

\section{ACKNOWLEDGEMENTS}

This material is based upon work supported in part by the Department of Veterans Affairs, Veterans Health Administration, Office of Research and Development of the Miami VA Healthcare System; by the Department of Medicine, Sylvester Comprehensive Cancer Center; and Division of Hematology/Oncology of the Miller Medical School, Miller School of Medicine, University of Miami; by the South Florida Veterans Affairs Foundation for Research and Education (all to A.V.S.). P.P. was supported by a stipend program of the Department of Medicine, Dresden, Germany and by the Helmholtz Alliance Imaging and Curing Environmental Metabolic Diseases through the Initiative and Networking Fund of the Helmholtz Association. F.G.R. received support from the Urology Care Foundation Research Scholars Program and the AUA Southeastern Section. The contents of this work do not represent the views of the Department of Veterans Affairs or the United States Government.

RP: Study design, animal protocol approval request (IACUC), animal studies, genetic analysis, data acquisition and analysis, manuscript preparation and revision. AS: Study design, peptide analog design, data analysis, manuscript preparation and revision. RC: Peptide analog design and synthesis and manuscript preparation. PP: Animal studies, efflux pump assay, and manuscript preparation. WS: Peptide analog purification, injectable drug formulation, and manuscript preparation. RR: Biosafety protocol approval request, cell culture, data analysis, and manuscript preparation. FR: Animal studies, data analysis, and manuscript preparation and revision. 


\section{REFERENCES}

1. CDC. (2010). Centers for Disease Control and Prevention: US Incidence of Breast Cancer.

2. Buchholz S, Seitz S, Schally AV, Engel JB, Rick FG, Szalontay L, Hohla F, Krishan A, Papadia A, Gaiser T, Brockhoff G, Ortmann O, Diedrich K and Koster F. Triplenegative breast cancers express receptors for luteinizing hormone-releasing hormone (LHRH) and respond to LHRH antagonist cetrorelix with growth inhibition. Int $\mathrm{J}$ Oncol. 2009; 35(4):789-796.

3. Dawson SJ, Provenzano E and Caldas C. Triple negative breast cancers: clinical and prognostic implications. Eur J Cancer. 2009; 45 Suppl 1(19775602):27-40.

4. Seitz S, Buchholz S, Schally AV, Jayakumar AR, Weber F, Papadia A, Rick FG, Szalontay L, Treszl A, Koster F, Ortmann $\mathrm{O}$ and Hohla F. Targeting triple-negative breast cancer through the somatostatin receptor with the new cytotoxic somatostatin analogue AN-162 [AEZS-124]. Anticancer Drugs. 2013; 24(2):150-157.

5. Bartsch R, Ziebermayr R, Zielinski CC and Steger GG. Triple-negative breast cancer. Wien Med Wochenschr. 2010; 160(20473728):174-181.

6. Schally AV, Varga JL and Engel JB. Antagonists of growthhormone-releasing hormone: an emerging new therapy for cancer. Nat Clin Pract Endocrinol Metab. 2008; 4(1):33-43.

7. Varga JL, Schally AV, Horvath JE, Kovacs M, Halmos G, Groot K, Toller GL, Rekasi Z and Zarandi M. Increased activity of antagonists of growth hormone-releasing hormone substituted at positions 8, 9, and 10. Proc Natl Acad Sci U S A. 2004; 101(14755056):1708-1713.

8. Szereday Z, Schally AV, Varga JL, Kanashiro CA, Hebert F, Armatis P, Groot K, Szepeshazi K, Halmos G and Busto $\mathrm{R}$. Antagonists of growth hormone-releasing hormone inhibit the proliferation of experimental non-small cell lung carcinoma. Cancer Res. 2003; 63(14633721):7913-7919.

9. Weiss-Messer E, Merom O, Adi A, Karry R, Bidosee M, Ber R, Kaploun A, Stein A and Barkey RJ. Growth hormone (GH) receptors in prostate cancer: gene expression in human tissues and cell lines and characterization, GH signaling and androgen receptor regulation in $\mathrm{LNCaP}$ cells. Molecular and Cellular Endocrinology. 2004; 220(1-2):109-123.

10. Rick FG, Schally AV, Block NL, Nadji M, Szepeshazi K, Zarandi M, Vidaurre I, Perez R, Halmos G and Szalontay L. Antagonists of growth hormone-releasing hormone (GHRH) reduce prostate size in experimental benign prostatic hyperplasia. Proc Natl Acad Sci U S A. 2011; 108(9):3755-3760.

11. Jaszberenyi M, Rick FG, Szalontay L, Block NL, Zarandi M, Cai RZ and Schally AV. Beneficial effects of novel antagonists of GHRH in different models of Alzheimer's disease. Aging. 2012; 4(11):755-767.

12. Lucas R, Sridhar S, Rick FG, Gorshkov B, Umapathy NS, Yang G, Oseghale A, Verin AD, Chakraborty T, Matthay MA, Zemskov EA, White R, Block NL and Schally AV.
Agonist of growth hormone-releasing hormone reduces pneumolysin-induced pulmonary permeability edema. Proc Natl Acad Sci U S A. 2012; 109(6):2084-2089.

13. Rick FG, Szalontay L, Schally AV, Block NL, Nadji M, Szepeshazi K, Vidaurre I, Zarandi M, Kovacs M and Rekasi Z. Combining growth hormone-releasing hormone antagonist with luteinizing hormone-releasing hormone antagonist greatly augments benign prostatic hyperplasia shrinkage. J Urol. 2012; 187(4):1498-1504.

14. Rick FG, Schally AV, Block NL, Abi-Chaker A, Krishan A and Szalontay L. Mechanisms of synergism between antagonists of growth hormone-releasing hormone and antagonists of luteinizing hormone-releasing hormone in shrinking experimental benign prostatic hyperplasia. Prostate. 2013; 73(8):873-883.

15. Rick FG, Saadat SH, Szalontay L, Block NL, Kazzazi A, Djavan B and Schally AV. Hormonal manipulation of benign prostatic hyperplasia. Curr Opin Urol. 2013; 23(1):17-24.

16. Czikora I, Sridhar S, Gorshkov B, Kasa A, Alieva I, Gonzales J, Potapenko O, Umapathy NS, Verin AD, Pillich H, Rick FG, Block NL, Chakraborty T, Matthay MA, Schally AV and Lucas R. Protective effect of Growth Hormone-Releasing Hormone agonist in bacterial toxininduced pulmonary barrier dysfunction. Frontiers in Physiology. 2014; 5.

17. Havt A, Schally AV, Halmos G, Varga JL, Toller GL, Horvath JE, Szepeshazi K, Koster F, Kovitz K, Groot $\mathrm{K}$, Zarandi $\mathrm{M}$ and Kanashiro CA. The expression of the pituitary growth hormone-releasing hormone receptor and its splice variants in normal and neoplastic human tissues. Proc Natl Acad Sci U S A. 2005; 102(16299104):1742417429.

18. Heinrich E, Schally AV, Buchholz S, Rick FG, Halmos G, Mile M, Groot K, Hohla F, Zarandi M and Varga JL. Dose-dependent growth inhibition in vivo of PC-3 prostate cancer with a reduction in tumoral growth factors after therapy with GHRH antagonist MZ-J-7-138. Prostate. 2008; 68(16):1763-1772.

19. Kovacs M, Schally AV, Hohla F, Rick FG, Pozsgai E, Szalontay L, Varga JL and Zarandi M. A correlation of endocrine and anticancer effects of some antagonists of GHRH. Peptides. 2010; 31(10):1839-1846.

20. Pozsgai E, Schally AV, Hocsak E, Zarandi M, Rick F and Bellyei S. The effect of a novel antagonist of growth hormone releasing hormone on cell proliferation and on the key cell signaling pathways in nine different breast cancer cell lines. Int J Oncol. 2011; 39(4):1025-1032.

21. Papadia A, Schally AV, Halmos G, Varga JL, Seitz S, Buchholz S, Rick F, Zarandi M, Bellyei S, Treszl A, Szalontay L and Lucci JA. Growth hormone-releasing hormone antagonists inhibit growth of human ovarian cancer. Horm Metab Res. 2011; 43(11):816-820.

22. Abdel-Wahab M, Schally AV, Rick FG, Szalontay L, Block NL, Jorda M, Mahmoud O, Markoe A, Shi Y-F, Reiner T, 
Zarandi M and Duncan R. Antagonists of growth hormone releasing hormone (GHRH) given before whole body radiation lead to modulation of radiation response and organ-specific changes in the expression of angiogenesis. J Radiat Oncol. 2012; 1(4):389-396.

23. Rick FG, Schally AV, Szalontay L, Block NL, Szepeshazi K, Nadji M, Zarandi M, Hohla F, Buchholz S and Seitz S. Antagonists of growth hormone-releasing hormone inhibit growth of androgen-independent prostate cancer through inactivation of ERK and Akt kinases. Proc Natl Acad Sci U S A. 2012; 109(5):1655-1660.

24. Rick FG, Seitz S, Schally AV, Szalontay L, Krishan A, Datz C, Stadlmayr A, Buchholz S, Block NL and Hohla F. GHRH antagonist when combined with cytotoxic agents induces S-phase arrest and additive growth inhibition of human colon cancer. Cell Cycle. 2012; 11(22):4203-4210.

25. Stangelberger A, Schally AV, Rick FG, Varga JL, Baker B, Zarandi $\mathrm{M}$ and Halmos $\mathrm{G}$. Inhibitory effects of antagonists of growth hormone releasing hormone on experimental prostate cancers are associated with upregulation of wildtype p53 and decrease in p21 and mutant p53 proteins. Prostate. 2012; 72(5):555-565.

26. Jaszberenyi M, Schally AV, Block NL, Zarandi M, Cai RZ, Vidaurre I, Szalontay L, Jayakumar AR and Rick FG. Suppression of the proliferation of human U-87 MG glioblastoma cells by new antagonists of growth hormonereleasing hormone in vivo and in vitro. Targeted oncology. 2013; 8(4):281-290.

27. Seitz S, Rick FG, Schally AV, Treszl A, Hohla F, Szalontay L, Zarandi M, Ortmann O, Engel JB and Buchholz S. Combination of GHRH antagonists and docetaxel shows experimental effectiveness for the treatment of triplenegative breast cancers. Oncol Rep. 2013; 30(1):413-418.

28. Szalontay L, Schally AV, Popovics P, Vidaurre I, Krishan A, Zarandi M, Cai RZ, Klukovits A, Block NL and Rick FG. Novel GHRH antagonists suppress the growth of human malignant melanoma by restoring nuclear p27 function. Cell Cycle. 2014.

29. Kiaris H, Schally AV, Varga JL, Groot K and Armatis P. Growth hormone-releasing hormone: an autocrine growth factor for small cell lung carcinoma. Proc Natl Acad Sci U S A. 1999; 96(26):14894-14898.

30. Schally AV. New approaches to the therapy of various tumors based on peptide analogues. Horm Metab Res. 2008; 40(5):315-322.

31. Fahrenholtz CD, Rick FG, Garcia MI, Zarandi M, Cai RZ, Block NL, Schally AV and Burnstein KL. Preclinical efficacy of growth hormone-releasing hormone antagonists for androgen-dependent and castration-resistant human prostate cancer. Proc Natl Acad Sci U S A. 2014; 111(3):1084-1089.

32. Siriwardana G, Bradford A, Coy D and Zeitler P. Autocrine/ paracrine regulation of breast cancer cell proliferation by growth hormone releasing hormone via Ras, Raf, and mitogen-activated protein kinase. Mol Endocrinol. 2006;
20(9):2010-2019.

33. Rekasi Z, Czompoly T, Schally AV and Halmos G. Isolation and sequencing of cDNAs for splice variants of growth hormone-releasing hormone receptors from human cancers. Proc Natl Acad Sci U S A. 2000; 97(19):10561-10566.

34. Csernus VJ, Schally AV, Kiaris H and Armatis P. Inhibition of growth, production of insulin-like growth factor-II (IGFII), and expression of IGF-II mRNA of human cancer cell lines by antagonistic analogs of growth hormone-releasing hormone in vitro. Proc Natl Acad Sci U S A. 1999; 96(10077643):3098-3103.

35. Kiaris H, Chatzistamou I, Schally AV, Halmos G, Varga JL, Koutselini $\mathrm{H}$ and Kalofoutis A. Ligand-dependent and -independent effects of splice variant 1 of growth hormonereleasing hormone receptor. Proc Natl Acad Sci U S A. 2003; 100(16):9512-9517.

36. Perez RS, AV; Vidaurre, I; Rincon, R; Block, NL; Rick, FG. Antagonists of growth hormone-releasing hormone suppress in vivo tumor growth and gene expression in triple negative breast cancers. Oncotarget. 2012; 3(9):988-997.

37. Gerger A, Renner W, Langsenlehner T, Hofmann G, Knechtel G, Szkandera J, Samonigg H, Krippl P and Langsenlehner U. Association of interleukin-10 gene variation with breast cancer prognosis. Breast Cancer Res Treat. 2010; 119(19437115):701-705.

38. Tawara K, Oxford JT and Jorcyk CL. Clinical significance of interleukin (IL)-6 in cancer metastasis to bone: potential of anti-IL-6 therapies. Cancer Manag Res. 2011; 3(21625400):177-189.

39. Zhao X, Sun X, Gao F, Luo J and Sun Z. Effects of ulinastatin and docataxel on breast tumor growth and expression of IL-6, IL-8, and TNF-alpha. J Exp Clin Cancer Res. 2011; 30(1):22.

40. Szepeshazi K, Schally AV, Block NL, Halmos G, Nadji M, Szalontay L, Vidaurre I, Abi-Chaker A and Rick FG. Powerful inhibition of experimental human pancreatic cancers by receptor targeted cytotoxic LH-RH analog AEZS-108. Oncotarget. 2013; 4(5):751-760.

41. Schally AV, Varga JL and Engel JB. Antagonists of growthhormone-releasing hormone: an emerging new therapy for cancer. Nature Clinical Practice Endocrinology \&\#38; Metabolism. 2008; 4(1):33-43.

42. Khorram O, Garthwaite M, Grosen E and Golos T. Human uterine and ovarian expression of growth hormonereleasing hormone messenger RNA in benign and malignant gynecologic conditions. Fertil Steril. 2001; 75(11163834):174-179.

43. Hohla F, Schally AV, Szepeshazi K, Varga JL, Buchholz S, Koster F, Heinrich E, Halmos G, Rick FG, Kannadka C, Datz C and Kanashiro CA. Synergistic inhibition of growth of lung carcinomas by antagonists of growth hormonereleasing hormone in combination with docetaxel. Proc Natl Acad Sci U S A. 2006; 103(16983095):14513-14518.

44. Kanashiro CA, Schally AV, Groot K, Armatis P, 
Bernardino ALF and Varga JL. Inhibition of mutant p53 expression and growth of DMS-153 small cell lung carcinoma by antagonists of growth hormone-releasing hormone and bombesin. Proc Natl Acad Sci U S A. 2003; 100(14660794):15836-15841.

45. Maitland NJ and Collins AT. Prostate Cancer Stem Cells: A New Target for Therapy. Journal of Clinical Oncology. 2008; 26(17):2862-2870.

46. Pradhan M, Bembinster LA, Baumgarten SC and Frasor J. Proinflammatory cytokines enhance estrogen-dependent expression of the multidrug transporter gene ABCG2 through estrogen receptor and NF \{kappa $\} \mathrm{B}$ cooperativity at adjacent response elements. J Biol Chem. 2010; 285(41):31100-31106.

47. Sullivan NJ, Sasser AK, Axel AE, Vesuna F, Raman V, Ramirez N, Oberyszyn TM and Hall BM. Interleukin-6 induces an epithelial-mesenchymal transition phenotype in human breast cancer cells. Oncogene. 2009; 28(19581928):2940-2947

48. Iliopoulos D, Hirsch HA, Wang G and Struhl K. Inducible formation of breast cancer stem cells and their dynamic equilibrium with non-stem cancer cells via IL6 secretion. Proc Natl Acad Sci U S A. 2011; 108(21220315):13971402.

49. Guo W, Lasky JL, Chang C-J, Mosessian S, Lewis X, Xiao Y, Yeh JE, Chen JY, Iruela-Arispe ML, Varella-Garcia M and $\mathrm{Wu} \mathrm{H}$. Multi-genetic events collaboratively contribute to Pten-null leukaemia stem-cell formation. Nature. 2008; 453(18463637):529-533.

50. Lopez-Novoa JM and Nieto MA. Inflammation and EMT: an alliance towards organ fibrosis and cancer progression. EMBO Mol Med. 2009; 1(6-7):303-314.

51. Hugo H, Ackland ML, Blick T, Lawrence MG, Clements JA, Williams ED and Thompson EW. Epithelial-mesenchymal and mesenchymal--epithelial transitions in carcinoma progression. J Cell Physiol. 2007; 213(2):374383.

52. Soria G, Ofri-Shahak M, Haas I, Yaal-Hahoshen N, LeiderTrejo L, Leibovich-Rivkin T, Weitzenfeld P, Meshel T, Shabtai E, Gutman M and Ben-Baruch A. Inflammatory mediators in breast cancer: Coordinated expression of TNF $\alpha$ $\&$ IL-1 $\beta$ with CCL2 \& CCL5 and effects on epithelial-tomesenchymal transition. BMC Cancer. 2011; 11(1):130.

53. Rick FG, Schally AV, Block NL, Nadji M, Szepeshazi K, Zarandi M, Vidaurre I, Perez R, Halmos G and Szalontay L. Antagonists of growth hormone-releasing hormone $(\mathrm{GHRH})$ reduce prostate size in experimental benign prostatic hyperplasia. Proc Natl Acad Sci U S A. 2011; 108(21321192):3755-3760.

54. Hohla F, Winder T, Greil R, Rick FG, Block NL and Schally AV. Targeted therapy in advanced metastatic colorectal cancer: Current concepts and perspectives. World journal of gastroenterology : WJG. 2014; 20(20):6102-6112.

55. Hohla F, Buchholz S, Schally AV, Seitz S, Rick FG, Szalontay L, Varga JL, Zarandi M, Halmos G, Vidaurre
I, Krishan A, Kurtoglu M, Chandna S, Aigner E and Datz C. GHRH antagonist causes DNA damage leading to p21 mediated cell cycle arrest and apoptosis in human colon cancer cells. Cell Cycle. 2009; 8(19):3149-3156.

56. Rick FG, Abi-Chaker A, Szalontay L, Perez R, Jaszberenyi M, Jayakumar AR, Shamaladevi N, Szepeshazi K, Vidaurre I, Halmos G, Krishan A, Block NL and Schally AV. Shrinkage of experimental benign prostatic hyperplasia and reduction of prostatic cell volume by a gastrin-releasing peptide antagonist. Proc Natl Acad Sci U S A. 2013; 110(7):2617-2622.

57. Seitz S, Hohla F, Schally AV, Moder A, Engel JB, Horn F, Varga J, Zarandi M, Ortmann O, Koster F and Buchholz S. Inhibition of estrogen receptor positive and negative breast cancer cell lines with a growth hormone-releasing hormone antagonist. Oncol Rep. 2008; 20(5):1289-1294.

58. Koster F, Engel JB, Schally AV, Honig A, Schroer A, Seitz S, Hohla F, Ortmann O, Diedrich K and Buchholz S. Triple-negative breast cancers express receptors for growth hormone-releasing hormone (GHRH) and respond to GHRH antagonists with growth inhibition. Breast Cancer Res Treat. 2009; 116(2):273-279.

59. Zarandi M, Horvath JE, Halmos G, Pinski J, Nagy A, Groot K, Rekasi Z and Schally AV. Synthesis and biological activities of highly potent antagonists of growth hormonereleasing hormone. Proc Natl Acad Sci U S A. 1994; 91(25):12298-12302.

60. Rick FG, Buchholz S, Schally AV, Szalontay L, Krishan A, Datz C, Stadlmayr A, Aigner E, Perez R, Seitz S, Block NL and Hohla F. Combination of gastrin-releasing peptide antagonist with cytotoxic agents produces synergistic inhibition of growth of human experimental colon cancers. Cell Cycle. 2012; 11(13):2518-2525.

61. Vandesompele J, De Preter K, Pattyn F, Poppe B, Van Roy N, De Paepe A and Speleman F. Accurate normalization of real-time quantitative RT-PCR data by geometric averaging of multiple internal control genes. Genome Biol. 2002; 3(7):RESEARCH0034.

62. Szepeshazi K, Schally AV, Keller G, Block NL, Benten D, Halmos G, Szalontay L, Vidaurre I, Jaszberenyi M and Rick FG. Receptor-targeted therapy of human experimental urinary bladder cancers with cytotoxic LH-RH analog AN152 [AEZS- 108]. Oncotarget. 2012; 3(7):686-699. 